\title{
Staging tables for avian embryos: a little history
}

\author{
CLAUDIO D. STERN* \\ Department of Cell \& Developmental Biology, University College London, London, UK.
}

\begin{abstract}
Absolute time elapsed since fertilization, or hours' incubation, is not a good measure of the precise degree of development of an embryo because there is considerable variation. The chick embryo benefits from a detailed, well defined staging system introduced by Hamburger and Hamilton in 1951, perhaps the most precise and detailed available for any species. This paper briefly reviews the background and legacy of this table, including the remarkable work of its predecessors, Mathias Duval and Franz Keibel. It also begs the question of why the mouse embryo still lacks a similarly precise classification.
\end{abstract}

KEY WORDS: Hamburger and Hamilton, chick embryo, quail embryo, staging system, developmental time, chronology

\section{History leading to the Hamburger and Hamilton (1951) tables}

About 2 years ago, Ruth Bellairs came to my office bearing a few gifts - material that she had put aside while tidying up her home. One was a reprint of a wonderful paper about somites from more than 100 years ago (Williams, 1910), another was a reprint of a curious paper describing the stages of development of the domestic penguin (Herbert, 1967) and the third was a large, hardcover book, the second volume of a series entitled "Normentafeln zur Entwicklungsgeschichte der Wirbelthiere" (edited by Prof. Dr. F. Keibel) - this second volume is entitled "Normentafel zur Entwicklungsgeschichte des Huhnes (Gallus domesticus)" [Normal table for development of the chick], co-authored by Keibel and Karl Abraham and published in Jena in 1900 (Keibel and Abraham, 1900). I immediately noticed a strong similarity between the numbers written above each stage illustrated and the stages of development as defined by Hamburger and Hamilton (Hamburger and Hamilton, 1951), the standard tables of chick development in use today.

Somehow I had missed finding this work earlier, as well as the two wonderful histories about stage tables written by Nick Hopwood (Hopwood, 2005, Hopwood, 2007). Therefore what follows here is a "little" history and focused on avian embryos, mainly for our avian embryology colleagues who were not aware of how these tables came to be, and their variations.

Hamburger and Hamilton cite the earlier work (among only 7 references cited in their paper), but only once, in passing: "Keibel and Abraham (1900) worked out a series of stages of the chick embryo based on morphological characters. This series never became popular and it has been rarely used and quoted. Among its shortcomings are its inadequate illustrations which often make the identification of an embryo difficult, the incomplete coverage of older stages, and perhaps also the format and relative inaccessibility of the Normentafeln.". But that is the only credit to what is really rather a remarkable piece of work. Keibel and Abraham accompany their drawings (Fig. 1) with a series of tables, two pages wide, where each row is a stage and the columns denote various characteristics that are used to define each stage (Fig. 2). Many of these include very precisely chosen characteristics. The 1900 book contains 42 pages of references to other literature, not restricted to the chick, a striking example of scholarship. So although Hamburger and Hamilton are correct that the illustrations are not photographs but drawings, they are far from inadequate and occasionally clearer than Hamburger and Hamilton's dark photographs, and quite useful for defining the stages of development. Hamburger and Hamilton are correct, however, that this has always been a rather obscure work and rarely cited, perhaps because it was published in German and as a book, both of which justify their accusation of "relative inaccessibility". This is certainly even more true today.

The Hamburger and Hamilton stage tables arose as a project because Howard Hamilton had been asked to produce a table of chick development stages to complement the following edition of "Lillie's Development of the Chick" by Frank R. Lillie (Lillie and Hamilton, 1952). In 1948, Hamilton met Viktor Hamburger and they discussed the idea of compiling a table based on stage numbers rather than time of incubation (Navis, 2007). This is what Keibel and Abraham had also done in their 1900 publication, as well as in

Abbreviations used in this paper: $\mathrm{H} \& \mathrm{H}$, Hamburger \& Hamilton (developmental stage). *Address correspondence to: Claudio D. Stern. Department of Cell \& Developmental Biology, University College London, Gower Street (Anatomy Building), London
WC1E 6BT, U.K. E-mail: c.stern @ ucl.ac.uk - (ID) http://orcid.org/0000-0002-9907-889X 


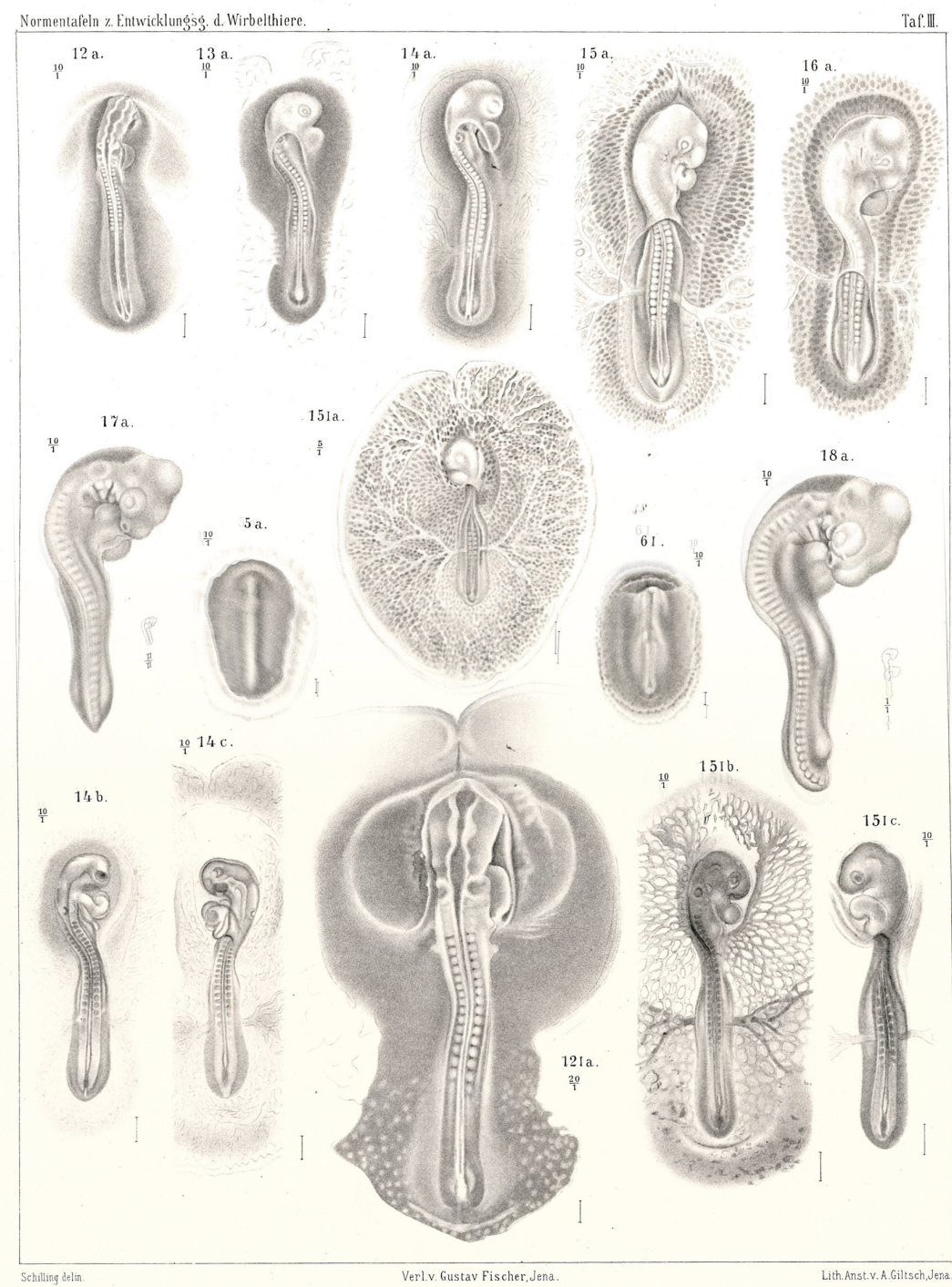

other volumes of an extensive series of stage tables for different species of vertebrate embryos edited by Keibel between 1897-1925, followed by a few posthumous volumes (see below).

Keibel and Abraham were not the first to produce such tables defining the stages of avian development. In 1889, Mathias Duval (1844-1907), Professor of Histology in the Faculty of Medicine in Paris who also taught anatomy for artists at the École Supérieure des Beaux-Arts (Fig. 3) produced a beautiful "Atlas d'Embryologie" published in Paris in 1889 (Duval, 1889 ), with 24 pages of narrative text mainly describing his methodology, 40 stunning tables of drawings (652 figures), some of them in colour (Fig. 4) and no less than 116 pages of explanations about the figures and the stages they represent. Although the Atlas is primarily what its name suggests, Duval takes care to classify the stages of development as precisely as possible and to define each as clearly as possible. About this work, which is another of Hamburger and Hamilton's 7 references, the latter authors merely say: “M. Duval's masterfulAtlas d'Embryologie (1889) with its artistically perfect drawings is unfortunately incomplete in that it does not go beyond the 8th day of incubation.". But the most remarkable feature of Duval's atlas is that unlike those that succeeded it, it includes many histological sections, illustrated with great accuracy (Fig. 4).

Fig. 1 (Left). Figure 3 of Keibel and Abraham (1900) showing embryos at stages 12-18. Note that these are closely equivalent to the homonymous Hamburger and Hamilton stages.

Fig. 2 (Below). Part of the extended tables listing characteristics of each developmental stage from Keibel and Abraham (1900), here covering their stages 8-13. Stage 8 is defined as having 3 somites, equivalent to HH stage 8 -.

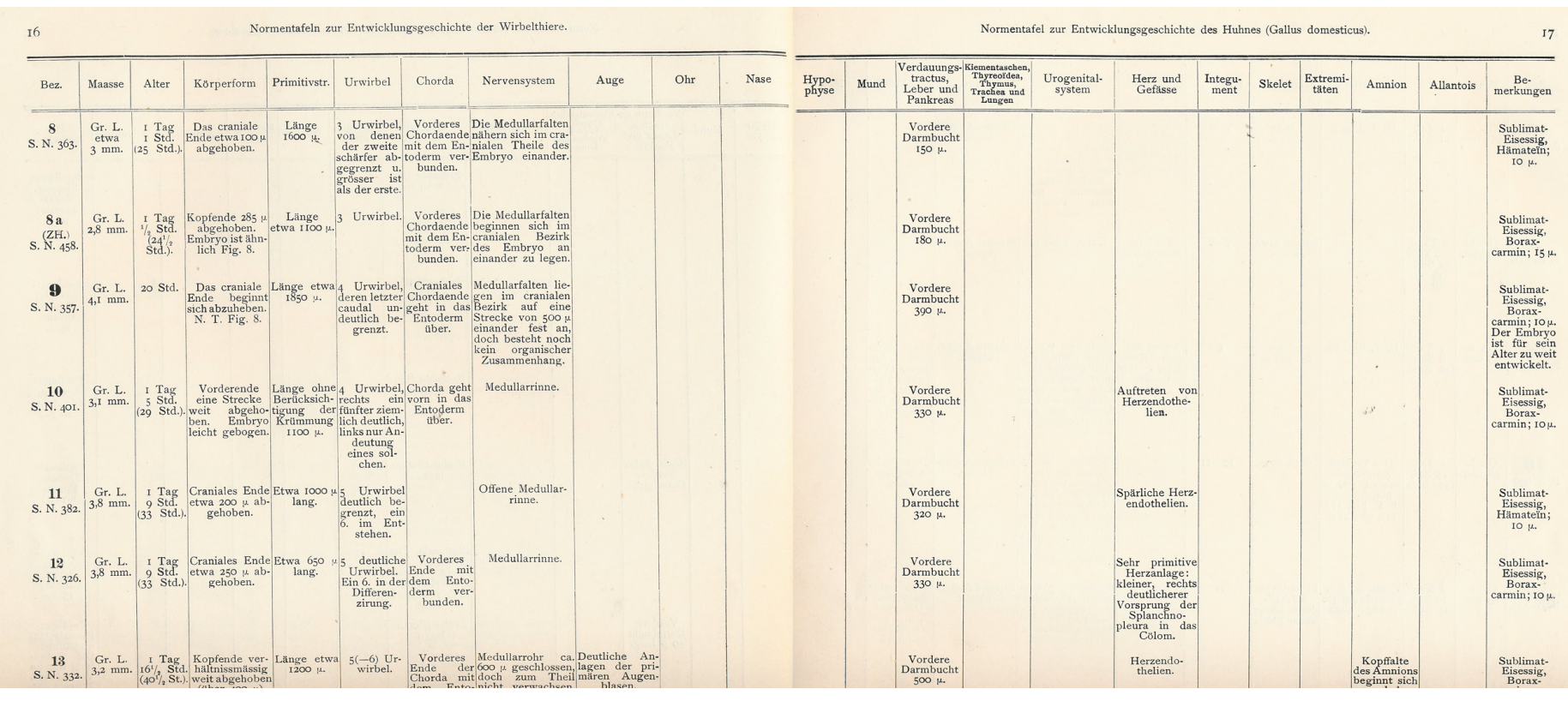




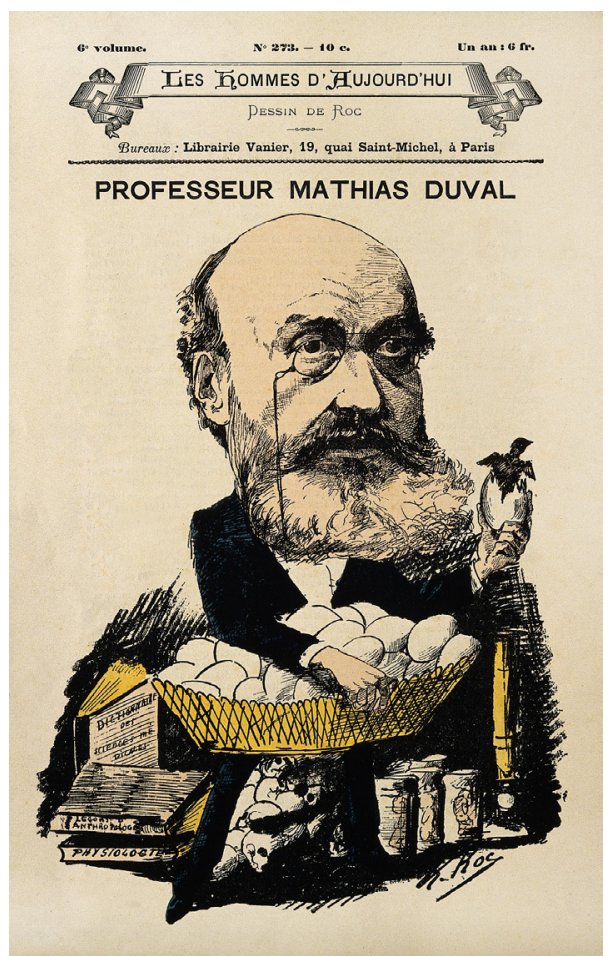

Fig. 3 (Above). Caricature of Mathias Duval (1844-1907) with eggs. Colour lithograph by L. Roc. Wellcome Library no. 2692i, photo number V0001730. FromWellcome Images (http://wellcomeimages.org/indexplus/ imageN0001730.htm/).

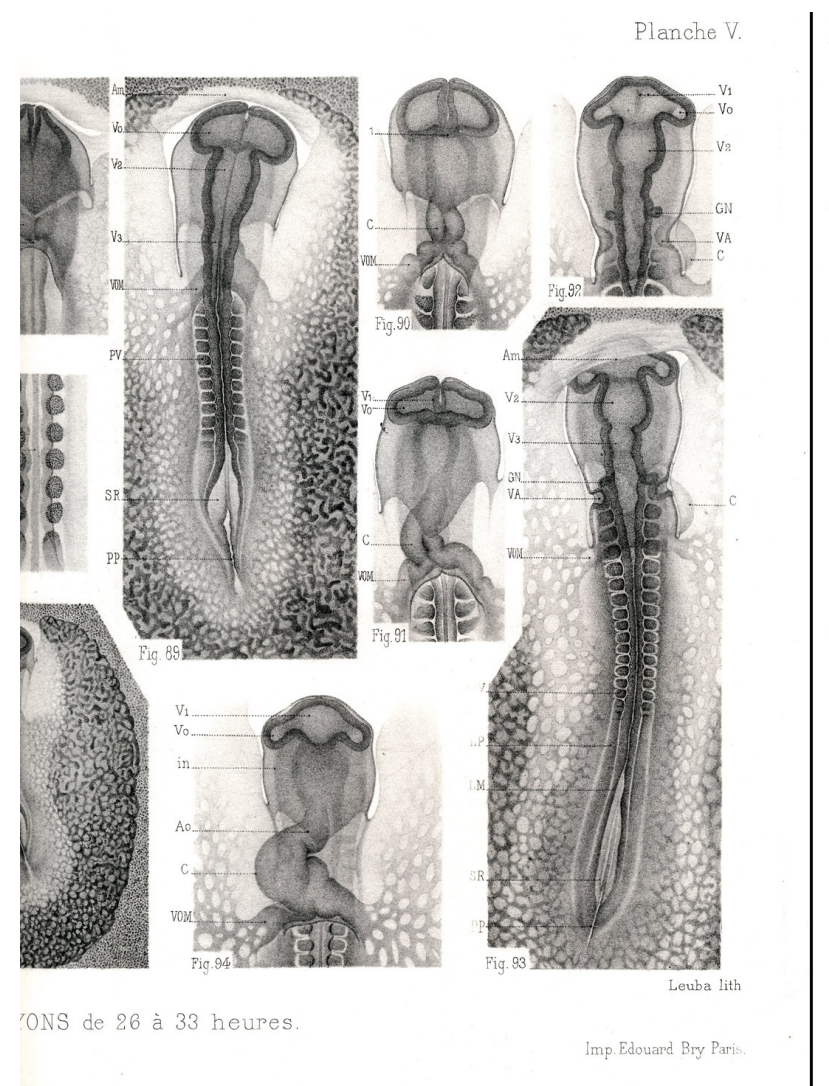

Attempts to classify chick embryonic development into a series of stages stretch much further back in history, though. Joseph Needham claims that the ancient Egyptians observed the development of the embryo by opening eggs on a daily basis and dates the practice of artificial incubation to 3000 B.C. (5000 years ago) (Needham, 1934). Observation of stages of development in the egg was continued by Aristotle (around 300 B.C.) who also described how several features change from day to day. But probably the first detailed description of chick development at different stages dates back to the end of the XVI century, in the work of Hieronymus Fabricius of Acquapendente (1537-1619) who produced excellent engravings of chick embryos at various stages of development (Fig. 5 ), although his descriptions are not very systematic (Fabricius of Acquapendente, 1621). In the following years of the XVII century there were several other treatises that described various aspects of chick development. In Padua, Fabricius was the teacher of none other than Englishman William Harvey (1578-1657), who went on to use chick embryos to discover the circulation of the blood (Harvey, 1628, Harvey, 1651). Harvey's many other momentous discoveries that started from his observations of chick embryos in the egg include the idea that "omne vivum ex ovo" [all living beings arise from the egg], which gave a fatal blow to the notion that creatures could arise by solidification or other chemical processes from inanimate matter (Needham, 1934).

After Keibel and Abraham (1900), there were essentially no more normal tables of chick development published until Hamburger and Hamilton's in 1951. This latter table does have some shortcomings (for example in several instances the picture of the chosen stage

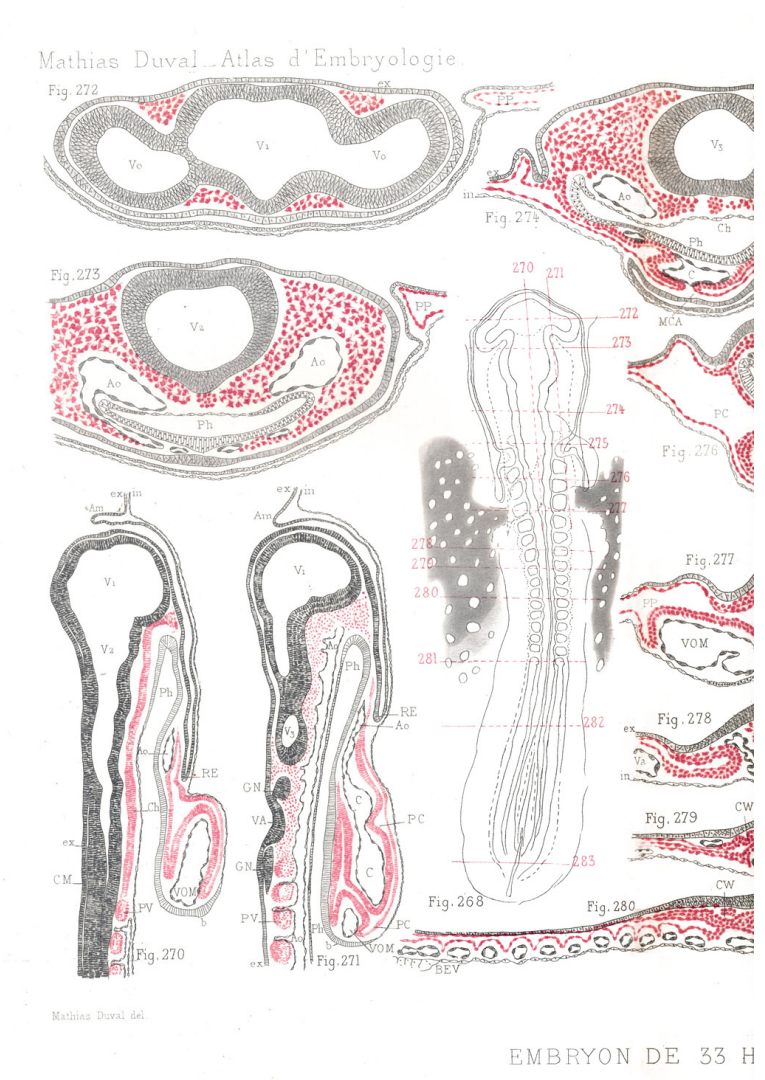

Fig. 4. Parts of two pages of the Atlas of Embryology of Mathias Duval (1889). These pages illustrate embryos at approximately HH10-13 in toto (left) and sections (right). 
does not entirely agree with the description of that stage, or is an abnormal embryo, for example for stage 4 [following the description in the text, the photograph is of a stage 4+ embryo] and embryos with abnormalities for stages 5 [bent streak posteriorly] and 6 [rather minimal/absent head fold which is the distinguishing feature of this stage]), and many of the photographs are very dark or lack critical detail. But apart from this, the descriptions are superb, the result of very careful observations, and the decisions of what to call "a stage", although largely based on Keibel and Abraham, has been made after considerable thought and observation of many embryos at each stage. It is for this reason that Hamburger and Hamilton (1951) remain the standard in the field, not only for chick embryos but it has also been extrapolated to other avian species (see below) and even constituted the blueprint for stages of development of the rabbit.

The Hamburger and Hamilton table was later (1992) reprinted in an issue of Developmental Dynamics with their own reference

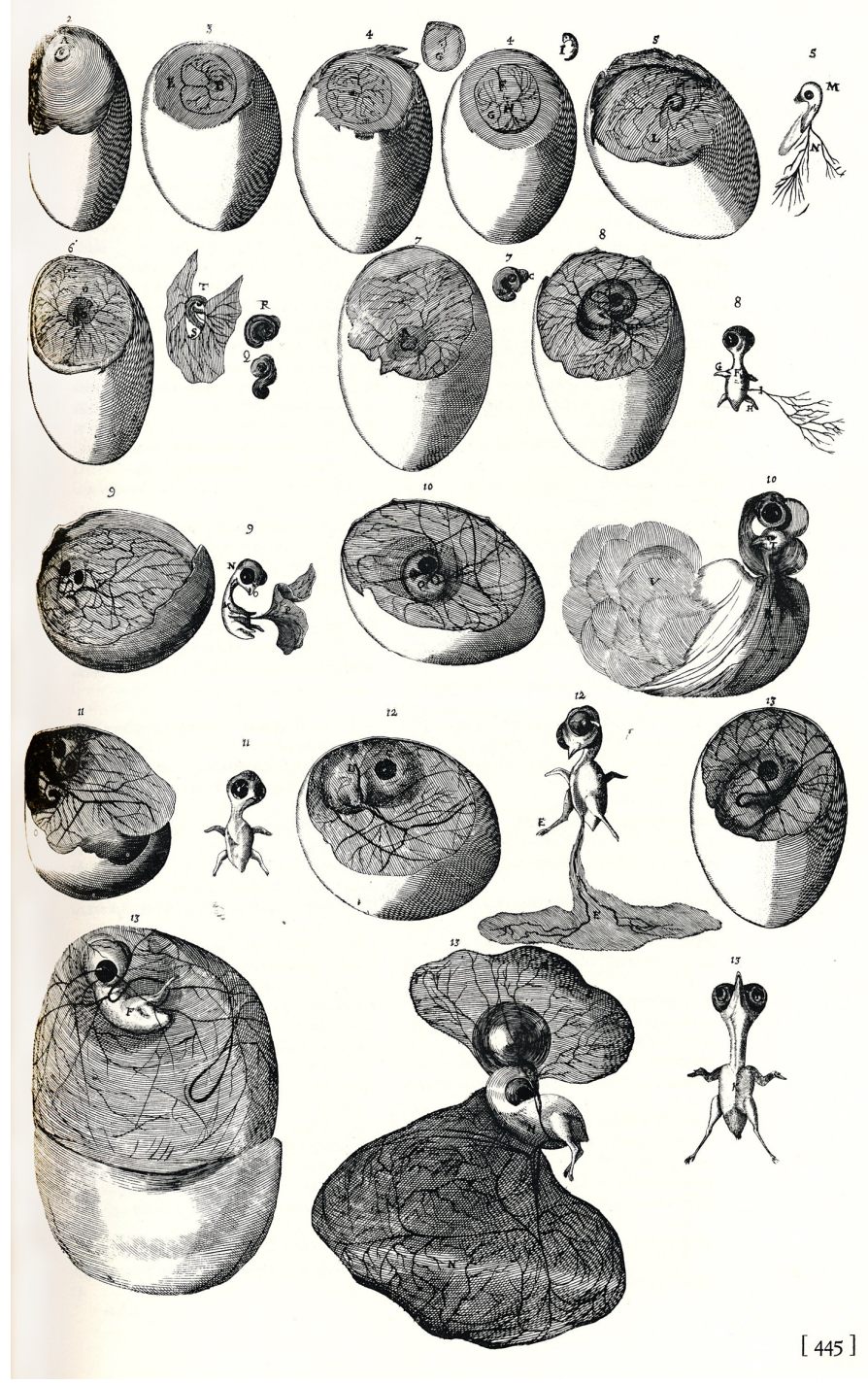

Fig. 5. A page of the treatise "De formatione ovi, et pulli ..." of Hieronymus Fabricius of Acquapendente (1621). This shows embryos at various stages of development, both in the egg and after explantation. (volume and pages) and it is unfortunate that sometimes Hamburger and Hamilton appear as if they produced their tables in 1992 - even though the republication makes the original more accessible, it is the original reference rather than the copy which should be cited. However the reprint of the tables is accompanied by a nice retrospective by Viktor Hamburger about how the tables were compiled (Hamburger, 1992).

\section{Variations on Hamburger and Hamilton and extension to earlier stages: Eyal-Giladi and Kochav (1976)}

Hamburger and Hamilton themselves suggest that intermediate stages between those they carefully describe should be denoted with + and - qualifiers, or with a fraction or decimal. This helps considerably in many cases for example, stage 7 is an embryo with 1 somite and stage 8 has 4 somites, so $7+$ has 2 somites and 8 - would have 3 somites. In some cases, interest in a particular set of stages has necessitated the introduction of a finer, and clearly defined subdivision. This is the case for the primitive streak stages. Vakaet suggested that Hamburger and Hamilton's $(\mathrm{HH})$ stages 1-4 should actually be subdivided into 7 stages (Vakaet, 1970). Although the stages as defined by him are indeed very useful, the system proposed is confusing because $\mathrm{HH}$ stage 4 would become stage 6 in the new system, which would then be followed by Vakaet stage 7 and then $\mathrm{HH}$ stages 5, 6 and another 7 before continuing. So it was never generally adopted. Schoenwolf attempted to do the same but subdividing $\mathrm{HH}$ stage 3 into four sub-stages, denoted 3a, 3b, 3c and 3d (Schoenwolf et al., 1992). A similar approach but following Hamburger and Hamilton's suggestion of using + and - for intermediate stages was proposed by Selleck and Stern (Selleck and Stern, 1991), where the stage 3 primitive streak has no groove and the epiblast above is still largely an unbroken epithelium, stage 3+ (Schoenwolf's stages $3 \mathrm{~b} / \mathrm{c}$ ) has a groove, stages 4 - and 4 can be distinguished by the shape of the node (bulbous in the latter stage, and the primitive pit having receded from the centre) (Schoenwolf stage $3 \mathrm{~d}$ ) and the presence of a small, triangular spike above the node corresponding to the incipient prechordal mesoderm at the tip of the future head process denotes stage 4+ (Vakaet stage 7, and corresponding to the figure, but not the text of $\mathrm{HH}$ stage 4). Precise definitions of these stages and a direct comparison between them has been published (Streit and Stern, 2008). This latter staging system (Selleck and Stern, 1991) is generally followed in the literature on primitive streak development.

Hamburger and Hamilton started their stage series with "HH 0 " and "HH 1" denoting embryos that lack a primitive streak, in the first few hours after egg laying. Even $\mathrm{HH}$ stage 0 represents an embryo that already has as many as 20,000 cells or more, and many developmental events take place before formation of the primitive streak. To classify these important stages of development, Eyal-Giladi and Kochav introduced a "complementary normal table", where $\mathrm{HHO}$ and $\mathrm{HH} 1$ are discarded, and the early developmental period, from the fertilized egg to just before the appearance of the primitive streak $\left(\mathrm{HH}_{2}\right)$ is subdivided into fourteen stages, denoted in Roman numerals: I-XIV (Eyal-Giladi and Kochav, 1976), which is widely used for these early stages. Therefore, the current standard is to use a combination of EyalGiladi and Kochav (1976) stages I-XIV, followed by Hamburger and Hamilton (1951) stages 2-45 (just before hatching), with + 
and - denoting intermediate stages as required. $\mathrm{HH}$ stages 0 and 1 are now obsolete and should not be used.

\section{Other avian, reptilian and mammalian species}

The chick staging series of Keibel and Abraham (1900) was published as the second volume in an extensive series of volumes (published between 1897-1925), edited by Franz Keibel (18611929), a German anatomist who worked successively in Freiburg, Strassburg, Königsberg and Berlin (see also Hopwood, 2005, 2007). The beautifully illustrated volumes define staging systems in the development of the pig (1897), chick (1900), lungfish (1901), sand lizard (1904), rabbit (1905), deer (1906), tarsiers (1907), human (1908), Northern lapwing (1909), South American and African lungfish (1909), salamander (1910), common mudpuppy (1911), spiny dogfish (1911), ground squirrel (1922) and common newt (Molge vulgaris) (1925). Afew more volumes published posthumously such as rat (1937) and large salamander (Megalobatrachus japonicus) (1938) (see review by Hopwood, 2007). This is an extraordinary contribution for which (along with his studies on human embryonic development) Keibel was rewarded with election to the German Academy of Sciences (Leopoldina) in 1926 and several honorary doctorates including from Harvard, St Andrews and Birmingham.

Staging tables (of variable quality) exist for several avian species. A more or less complete coverage of the entire embryonic period has been described for Japanese quail (Zacchei, 1961) (from stage 4 onwards also described by Ainsworth et al., 2010), Adélie penguin (Herbert, 1967), emu (Nagai et al., 2011), turkey (Mun and Kosin, 1960), pheasant (Fant, 1957), Pekin duck (Kaltofen, 1971), mallard duck (Anas boschas) (Koecke, 1958) (including comparison of these stages to those of Hamburger and Hamilton and of Keibel and Abraham), society finch (Yamasaki and Tonosaki, 1988), zebra finch (Murray et al., 2013) and lapwing (Grosser and Tandler, 1909). Partial tables are available for many other bird species, sources for a subset of which are listed in a comprehensive book (Starck and Ricklefs, 1998; see Table 2.3, page 40). It is interesting to compare these various stage tables with Hamburger and Hamilton and with Keibel and Abraham - it is quite obvious that in most cases, the staging criteria of either or both of these were used to guide the definition of stages for other species.

Interestingly, Hamburger and Hamilton's staging criteria have also guided the definition of stages of development of a reptile (Gecko) (Wise et al., 2009) and for very early stages of rabbit development (Viebahn et al., 1995). For the latter, a wider developmental period is covered in one of Keibel's volumes (Minot and Taylor, 1905 ) but this does not include a comprehensive series of stages.

\section{Why are stage tables important?}

Duval, Keibel and Hamburger were very aware that eggs incubated for the same length of time can vary considerably in their degree of development, even when within one same strain and when the eggs are incubated simultaneously. As absolute incubation time is an inaccurate measure of developmental progression, classification into distinct, definable stages allows different embryos to be compared more easily. Developmental events are inter-dependent; for example, the competence of a tissue to respond to a specific signal can be critically dependent on the stage of development, and can change dramatically within a very short time (see for example Dias and Schoenwolf, 1990, Storey et al., 1992, Streit etal., 1997). Without a precise staging system, it is virtually impossible to define this clearly, and the phenomenon itself may be missed. In this context, I have always been surprised that one of the major model systems in developmental biology, the laboratory mouse, has never been endowed with a rigorous staging system, apart from a very short period of development (around the primitive streak stage) (Downs and Davies, 1993). Much of the mouse developmental literature merely describes the stage of development in "d.p.c." (days post coitum), and often with a resolution of a whole day (as embryos are generally collected in the morning, embryos are usually stated as being $71 \frac{1}{2}$ d.p.c., $91 \frac{1}{2}$ d.p.c., etc.). Constructing a normal table of development as done by Keibel and Hamburger and Hamilton is a major undertaking, but it makes a huge difference to the precision with which experimental designs and results can be analysed and communicated to others. The history of the use of the Hamburger and Hamilton tables in the chick embryo (which to date have been cited about 13,000 times to date [Google Scholar - 11,593 to the original reference and 1,434 incorrect citations to the 1992 reprint in Dev. Dynamics]) has clearly demonstrated that some important events would not have been discovered at all were it not for the precision with which developmental stages are defined. Hopefully some colleagues with foresight and dedication comparable to the extraordinary efforts of Duval, Keibel and Hamburger and Hamilton will soon embark on the task of producing detailed stage tables for the mouse embryo, as well as for the rabbit. Together with the chick stages, these could then also help to refine the stage tables for human embryos beyond the relatively crude Carnegie staging system (O’Rahilly and Müller, 1987).

\section{References}

AINSWORTH, S.J., STANLEY, R.L. and EVANS, D.J. (2010). Developmental stages of the Japanese quail. $J$ Anat 216: 3-15.

DIAS, M.S. and SCHOENWOLF, G.C. (1990). Formation of ectopic neurepithelium in chick blastoderms: age-related capacities for induction and self-differentiation following transplantation of quail Hensen's nodes. Anat Rec 228: 437-448.

DOWNS, K.M. and DAVIES, T. (1993). Staging of gastrulating mouse embryos by morphological landmarks in the dissecting microscope. Development 118: 1255-1266.

DUVAL, M. (1889). Atlas d'embryologie. G. Masson, Paris.

EYAL-GILADI, H. and KOCHAV, S. (1976). From cleavage to primitive streak formation: a complementary normal table and a new look at the first stages of the development of the chick. I. General morphology. Dev Biol 49: 321-337.

FABRICIUS OF ACQUAPENDENTE, H. (1621). De formatione ovi, et pulli... Press of Aloyssius Bencius, Bookseller, Padua.

FANT, R.J. (1957). Criteria for aging pheasant embryos. J Wildlife Management 21: $324-328$

GROSSER, O. and TANDLER, J. (1909). Normentafel zur Entwicklungsgeschichte des Kiebitzes (Vanellus cristatus Meyer). Gustav Fischer Verlag., Jena.

HAMBURGER, V. (1992). The stage series of the chick embryo. Dev Dyn 195:273-275.

HAMBURGER, V. and HAMILTON, H.L. (1951). A series of normal stages in the development of the chick embryo. J Morphol 88: 49-92.

HARVEY, W. (1628). Exercitatio anatomica de motu cordis et sanguinis in animalibus. Guiliemi Fitzeri, Frankfurt.

HARVEY, W. (1651). Exercitationes de generatione animalium, London.

HERBERT, C. (1967). A timed series of embryonic developmental stages of the Adélie penguin (Pygoscelis adeliae) from Signy Island, South Orkney Islands. Br. Antarct. Surv. Bull. 14: 45-67.

HOPWOOD, N. (2005). Visual standards and disciplinary change: Normal plates, tables and stages in embryology. Hist. Sci. 43: 239-303. 
HOPWOOD, N. (2007). A history of normal plates, tables and stages in vertebrate embryology. Int J Dev Biol 51: 1-26.

KALTOFEN, R.S. (1971). Embryonic development in the eggs of the Pekin Duck/ Embryonalentwicklung in den eiern der Pekingente (bilingual). Centrum voor landbouwpublikaties en landbouwdocumentatie, Wageningen.

KEIBEL, F. and ABRAHAM, K. (1900). Normentafel zur Entwicklungsgeschichte des Huhnes (Gallus domesticus). Gustav Fischer, Jena.

KOECKE, H.U. (1958). Normalstadien der Embryonalentwicklung bei der Hausente (Anas boschas domestica). Embryologia 4: 55-78.

LILLIE, F.R. and HAMILTON, H.L. (1952). Lillie's Development of the Chick An Introduction to Embryology. Henry Holt and Company, [S.I.].

MINOT, C.S. and TAYLOR, E. (1905). Normal plates of the development of the rabbit (Lepus cuniculus L.). Gustav Fischer Verlag., Jena.

MUN, A.M. and KOSIN, I.L. (1960). Development of the broad breasted bronze turkey embryo. Biol Bull 119: 90-97.

MURRAY, J.R., VARIAN-RAMOS, C.W., WELCH, Z.S. and SAHA, M.S. (2013). Embryological staging of the Zebra Finch, Taeniopygia guttata. J Morphol 274: 1090-1110.

NAGAI, H., MAK, S.S., WENG, W., NAKAYA, Y., LADHER, R. and SHENG, G. (2011). Embryonic development of the emu, Dromaius novaehollandiae. Dev Dyn 240: 162-175.

NAVIS, A.R. (2007). A series of normal stages in the development of the chick embryo (1951) by Viktor Hamburger and Howard L. Hamilton. In Embryo Project Encyclopedia(2007-10-30). ISSN: 1940-5030 - http://embryo.asu.edu/handle/10776/1710

NEEDHAM, J. (1934). A history of embryology. Cambridge University Press, Cambridge.

O'RAHILLY, R. and MÜLLER, F. (1987). Developmental stages in human embryos, including a revision of Streeter's "Horizons" and a survey of the Carnegie Collection. Contrib. Embryol., Carnegie Inst. Wash. 637, Washington D.C.
SCHOENWOLF, G.C., GARCIA-MARTINEZ, V. and DIAS, M.S. (1992). Mesoderm movement and fate during avian gastrulation and neurulation. Dev Dyn 193 235-248

SELLECK, M.A. and STERN, C.D. (1991). Fate mapping and cell lineage analysis of Hensen's node in the chick embryo. Development 112: 615-626.

STARCK, J.M. and RICKLEFS, R.E. (1998). Avian growth and development: evolution within the altricial-precocial spectrum. Oxford University Press, New York; Oxford.

STOREY, K.G., CROSSLEY, J.M., DE ROBERTIS, E.M., NORRIS, W.E. and STERN C.D. (1992). Neural induction and regionalisation in the chick embryo. Develop ment 114: 729-741.

STREIT, A., SOCKANATHAN, S., PEREZ, L., REX, M., SCOTTING, P.J., SHARPE, P.T., LOVELL-BADGE, R. and STERN, C.D. (1997). Preventing the loss of competence for neural induction: HGF/SF, L5 and Sox-2. Development 124: 1191-1202.

STREIT, A. and STERN, C.D. (2008). Operations on primitive streak stage avian embryos. Methods Cell Biol 87: 3-17.

VAKAET, L. (1970). Cinephotomicrographic investigations of gastrulation in the chick blastoderm. Arch Biol 81: 387-426.

VIEBAHN, C., MAYER, B. and HRABE DE ANGELIS, M. (1995). Signs of the principle body axes prior to primitive streak formation in the rabbit embryo. Anat Embryol (Berl) 192: 159-69.

WILLIAMS, L.W. (1910). The somites of the chick. Amer J Anat 11: 55-100.

WISE, P.A., VICKARYOUS, M.K. and RUSSELL, A.P. (2009). An embryonic staging table for in ovo development of Eublepharis macularius, the leopard gecko. Anat Rec (Hoboken) 292: 1198-1212.

YAMASAKI, M. and TONOSAKI, A. (1988). Developmental stages of the Society Finch, Lonchura striata var. domestica. Dev. Growth Diff. 30: 515-542.

ZACCHEI, A.M. (1961). Lo sviluppo embrionale della quaglia giaponese (Coturnix coturnix japonica T. e S.). Arch Ital Anat Embriol 66: 36-62. 


\section{Further Related Reading, published previously in the Int. J. Dev. Biol.}

Hefzibah Eyal-Giladi (1925-2017): over fifty years of embryological research in Israel Oded Khaner

Int. J. Dev. Biol. (2017) 61: 121-126

https://doi.org/10.1387/ijdb.160179ok

\section{A history of normal plates, tables and stages in vertebrate embryology}

Nick Hopwood

Int. J. Dev. Biol. (2007) 51: 1-26

https://doi.org/10.1387/ijdb.062189nh

\section{A history of mammalian embryological research}

H Alexandre

Int. J. Dev. Biol. (2001) 45: 457-467

http://www.intjdevbiol.com/web/paper/11417885

The introduction of Xenopus laevis into developmental biology: of empire, pregnancy testing and ribosomal genes

J B Gurdon and N Hopwood

Int. J. Dev. Biol. (2000) 44: 43-50

http://www.intjdevbiol.com/web/paper/10761846

A treasure house of comparative embryology

M K Richardson and J Narraway

Int. J. Dev. Biol. (1999) 43: 591-602

http://www.intjdevbiol.com/web/paper/10668968

The chronological development of the urodele amphibian Pleurodeles waltl (Michah)

D L Shi and J C Boucaut

Int. J. Dev. Biol. (1995) 39: 427-441

http://www.intjdevbiol.com/web/paper/7577434

5 yr ISI Impact Factor $(2016)=2.421$
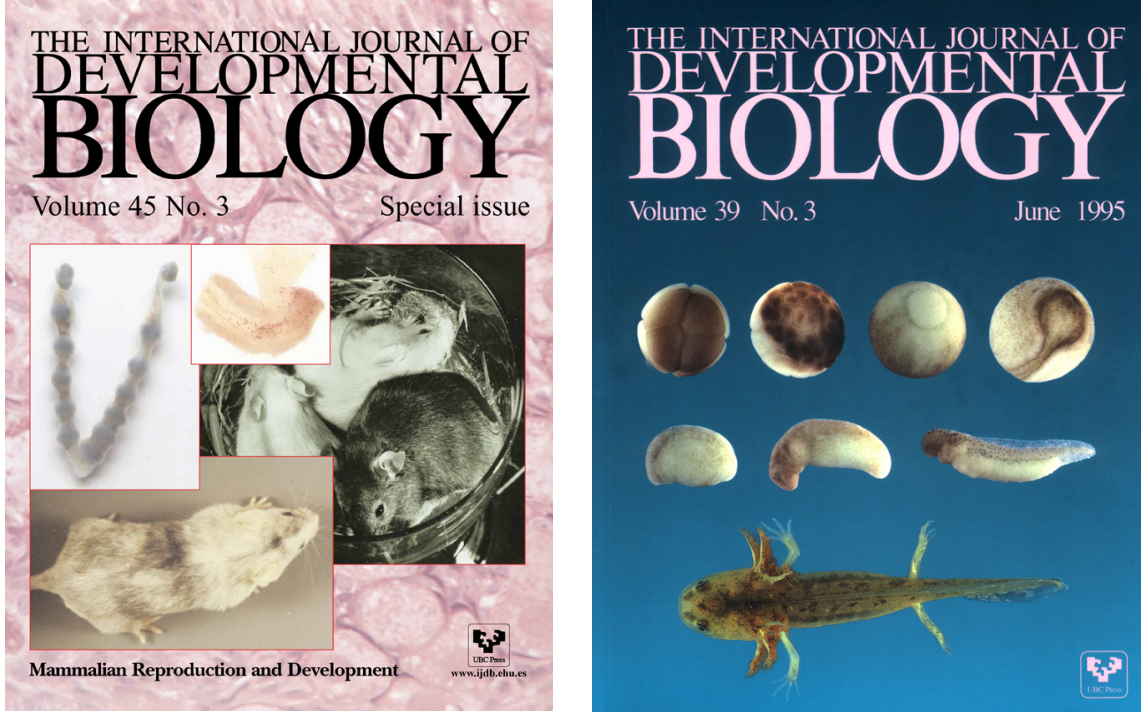

Volume 39 No. 3

June 1995

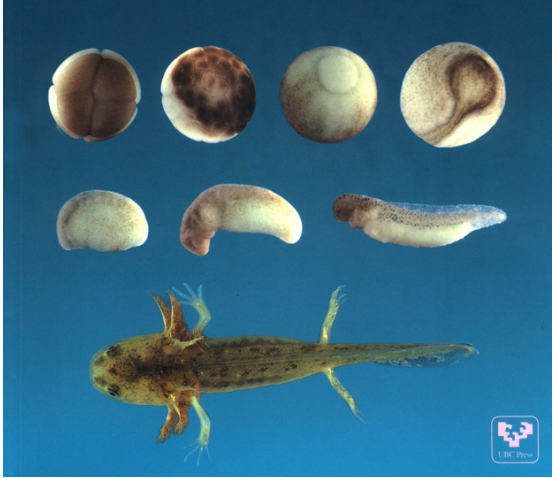

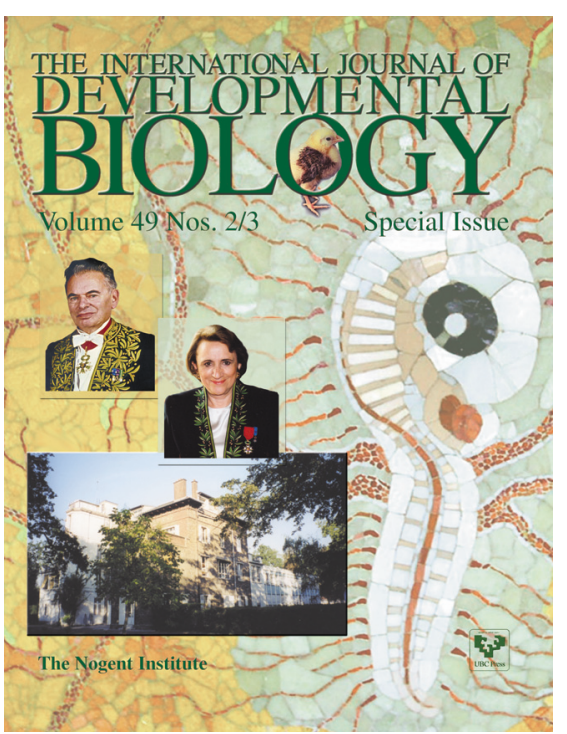
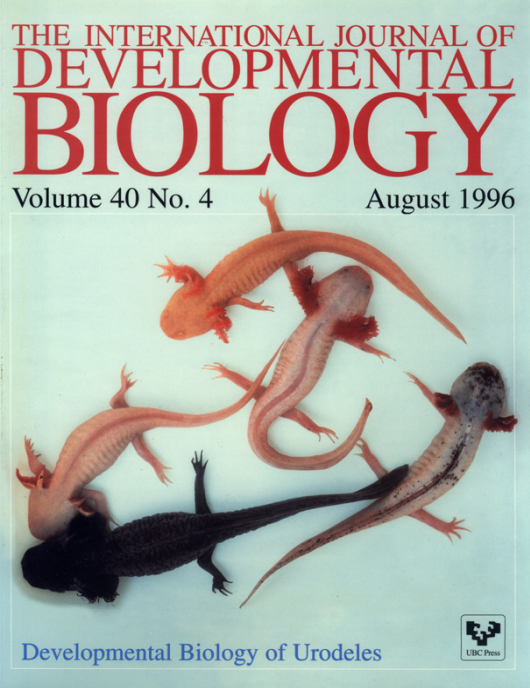